Jurnal Ilmu Ilmu Agribisnis: Journal of Agribusiness Science, 9(4), November 2021

\title{
ANALISIS USAHATANI DAN FAKTOR-FAKTOR YANG MEMPENGARUHI KEUNTUNGAN USAHATANI CABAI MERAH DI KECAMATAN TULANG BAWANG TENGAH KABUPATEN TULANG BAWANG BARAT
}

\author{
(Analyisis of Farming and Factors that Affecting Farming Profit of Red Chilli in Tulang Bawang \\ Tengah Subdistrict, Tulang Bawang Barat Regency)
}

Afaf Faadhilah Risyanti, Bustanul Arifin, dan Lina Marlina

\begin{abstract}
Jurusan Agribisnis, Fakultas Pertanian, Universitas Lampung, Jl. Prof. Dr. Soemantri Brojonegoro No. 1 Bandar Lampung, 35145,e-mail: bustanul.arifin@fp.unila.ac.id
\end{abstract}

\begin{abstract}
This study aims to analyze farming and factors that affecting the profit of red chilli farming in Tulang Bawang Tengah Sub-District, Tulang Bawang Barat Regency. This research uses survey method. The research is located in Tulang Bawang Tengah Sub-Distric, Tulang Bawang Barat Regency, which was conducted in April-May 2019. The number of respondent are 57 farmers taken by random sampling method. Data are analyzed using quantitative and qualitative analysis. Furthermore, farming analysis is analyzed using income analysis and by counting the value of $R / C$ to cash cost and total cost. Factors affecting profit function are analyzed by profit analysis UOP (Unit Output Price), which is a derived of the cobb douglas production function and normalized by output price. The results show that the average income of red chilli farming in Tulang Bawang Tengah Sub-District base on cash costs and the total cost is Rp47,486,701.79/hectare and Rp22,229,238.35/hectare, respectively. Red Chilli farming give a profit as the value of $R / C$ to cast costs and total cost are 1,99 and 1,33. Factors of land area, seed price, SP36 fertilizer price, manure price, NPK fertilizer price, insecticide price, fungicide price and labor wages significantly affect to the profits of red chilli farming in Tulang Bawang Tengah Subdistric.
\end{abstract}

Keywords : income, profit, and red chilli

Received: 21 January 2020 Revised: 8 May 2020 Accepted:18 June 2020 DOI: http://dx.doi.org/10.23960/jiia.v9i4.5395

\section{PENDAHULUAN}

Pada tahun 2017, permintaan nasional cabai merah keseluruhan masyarakat adalah $34.285 .714,29$ kuintal pada tahun 2017. Sementara itu, produksi cabai merah yang bisa dihasilkan di Indonesia pada tahun 2017 mencapai 21.540.446,43 kuintal. Hal ini mendorong pemerintah melakukan impor cabai dari negara lain seperti Malaysia sebesar 9.428,57 kuintal dan Vietnam sebesar 821,43 kuintal (BPS 2017).

Luas lahan cabai merah di Indonesia adalah 142.547 hektar dengan produksi sebesar 21.540.464,29 kuintal serta produktivitas adalah $151,11 \mathrm{kuintal} / \mathrm{hektar}$ pada tahun 2017. Provinsi Lampung merupakan salah satu provinsi dengan produksi cabai merah terbesar keempat di Sumatera yaitu sebesar 1.159.089.3 kuintal dengan lahan seluas 7.890 hektar dan produktivitas yang telah dicapai adalah 146,91 kuintal/hektar (BPS dan Dirjen Hortikultura 2017).
Usahatani cabai merah di Provinsi Lampung mengalami peningkatan produksi dan produktivitas di beberapa kabupaten. Produksi meningkat dari tahun 2014 sebesar 730.767,86 kuintal menjadi 8.964.857,14 kuintal pada tahun 2017. Produktivitas cabai merah di berbagai kabupaten di Provinsi Lampung meningkat dari 98,67 kuintal/hektar pada tahun 2014 menjadi 1.136,23 kuintal/hektar pada tahun 2017 (BPS 2017).

Kabupaten Tulang Bawang Barat adalah salah satu daerah yang memiliki produktivitas cabai merah terbesar ketiga pada tahun 2014 yaitu sebesar 7,47 kuintal/hektar. Produktivitas cabai merah di Kabupaten Tulang Bawang Barat meningkat menjadi 68 kuintal/hektar pada tahun 2017. Peningkatan produktivitas cabai merah di Tulang Bawang Barat yang signifikan dikarenakan peningkatan luas lahan yang digunakan untuk melakukan usahatani cabai merah oleh petani yaitu pada tahun 2014 sebesar 103 hektar dan meningkat sebesar 141 hektar pada tahun 2017 (BPS 2017). 
Kecamatan Tulang Bawang Tengah merupakan salah satu kecamatan yang memiliki luas lahan terbesar di Kabupaten Tulang Bawang Barat. Luas lahan usahatani cabai merah di Kecamatan Tulang Bawang Tengah yaitu sebesar 34 hektar dan produksi 3.550 kuintal pada tahun 2015. Usahatani cabai merah di Kecamatan Tulang Bawang Tengah paling banyak berada pada Desa Candra Jaya, Candra Kencana, dan Mulya Asri (Kecamatan Tulang Bawang Tengah 2018).

Curah hujan yang tidak menentu dapat merusak proses pertumbuhan tanaman cabai merah, selain itu, akibat iklim yang ekstrim dapat merusak tabaman cabai merah. Akibat yang terjadi dari kerusakan tanaman cabai merah adalah produksi yang menurun yang signifikan sehingga kenaikan harga produksi tidak dapat dihindarkan. Hal ini menyebabkan keuntungan petani cenderung mengalami penurunan hingga petani mengalami kerugian yang besar (Nofita, Sutiarso, dan Hadi 2016).

Permasalahan yang terjadi pada usahatani cabai merah di Kecamatan Tulang Bawang Tengah adalah lahan sempit, harga input (benih dan pestisida) yang mahal, harga cabai merah yang berfluktuasi, dan aspek teknologi yang rendah dalam melakukan usahatani. Petani di kecamatan ini hanya berorientasi pada produksi tanpa merinci secara detail pengeluaran untuk melakukan pengadaan input. Selain itu, petani kurang memiliki motivasi untuk melakukan perubahan dengan berorientasi pada pasar yang mengubah dari pertanian tradisional menjadi pertanian moderen.

Berdasarkan latar belakang dan perumusan masalah, maka penelitian ini memiliki tujuan menganalisis pendapatan usahatani dan keuntungan usahatani cabai merah serta menganalisis faktor - faktor yang mempengaruhi keuntungan usahatani cabai merah di Kecamatan Tulang Bawang Tengah, Kabupaten Tulang Bawang Barat.

\section{METODE PENELITIAN}

Metode penelitian yang digunakan pada penelitian ini adalah metode survei. Metode survei dilakukan dengan wawancara langsung dengan responden yang memiliki usahatani cabai merah. Jenis data yang dibutuhkan adalah data primer dan sekunder yang meliputi identitas responden, jumlah produksi, data input yang digunakan dalam melakukan usahatani, dan data lainnya yang berkaitan dengan penelitian. Pemilihan lokasi penelitian dilakukan secara sengaja (purposive) dengan Kecamatan Tulang Bawang Tengah sebagai Kecamatan sentra cabai merah di Kabupaten Tulang Bawang Barat dan telah ada sejak tahun 1982. Teknik pengambilan sampel adalah probability sampling dengan menggunakan proportionate random sampling. Menurut Sugiyono (2010), proportionate random sampling adalah teknik pengambilan sampel dimana populasi setiap wilayah yang diteliti heterogen dan dalam hal ini berbeda dalam besaran sampel sehingga pada masing-masing kelompok diambil secara proporsional untuk memperoleh sampling. Rumus yang digunakan dalam penentuan jumlah sampel menurut Sugiono (2010) adalah:

$\mathrm{n}=\frac{\mathrm{N}}{\mathrm{Nd}^{2}+1}$

Keterangan:

$\mathrm{n} \quad=$ Ukuran sampel

$\mathrm{N}=$ Ukuran populasi

$\mathrm{d}=$ Tingkat presisi (ditetapkan 10\% dengan tingkat kepercayaan 90\%)

Berdasarkan perhitungan tersebut, sampel yang dalam penelitian ini di sesuaikan menjadi sebanyak 57 petani dari seluruh total petani cabai merah. Setelah didapatkan jumlah responden dari populasi usahatani cabai merah yang terdiri dari tiga desa dalam satu kecamatan, untuk menentukan besaran jumlah responden usahatani cabai merah dalam tiap-tiap desa menggunakan rumus alokasi proposional sample (Nazir 2005), yaitu sebagai berikut:

$\mathrm{nh}=\frac{\mathrm{Nh} \times \mathrm{n}}{\mathrm{N}}$

Keterangan :

$\mathrm{n}_{\mathrm{h}} \quad=$ Jumlah sampel tiap Desa

$\mathrm{N}_{\mathrm{h}}=$ Jumlah populasi keseluruhan

$\mathrm{n}$ =Jumlah sampel keseluruhan

$\mathrm{N}=$ Jumlah populasi

Jumlah responden di Desa Candra Jaya adalah 111 responden, Desa Candra Kencana 13 responden dan Desa Mulya Asri 6 responden. Jadi jumlah sampel yang diambil peneliti per desa adalah :

a) responden Desa Candra Jaya

$\frac{111 \times 57}{130}=49$ responden

b) responden Desa Candra Kencana $\frac{13 \times 57}{130}=6$ responden 
c) responden Desa Mulya Asri

$$
\frac{6 \times 57}{130}=2 \text { responden }
$$

Berdasarkan perhitungan tersebut, jumlah responden yang akan diambil yaitu sebanyak 49 responden di Desa Candra Jaya, 6 responden di Desa Candra Kencana dan 2 responden di Desa Mulya Asri. Sampel petani cabai merah di Kecamatan Tulang Bawang Tengah diambil secara acak (Simple Random Sampling), yang artinya setiap petani cabai merah di Kecamatan Tulan Bawang Tengah memiliki peluang untuk menjadi sampel.

Penelitian ini menggunakan metode analisis kualitatif dan analisis kuantitatif. Pengumpulan data dilakukan melalui wawancara dan pengisian kuesioner. Analisis kuantitatif digunakan untuk menganalisis usahatani dan menganalisis faktorfaktor yang mempengaruhi pendapatan petani cabai merah. Analisis kualitatif digunakan untuk menjabarkan hasil analisis usahatani dan hasil faktor-faktor yang mempengaruhi keuntungan usahatani cabai merah di Kecamatan Tulang Bawang Tengah.

Pendapatan usahatani diperoleh dengan menghitung selisih antara penerimaan yang diterima dari hasil usahatani dengan total biaya produksi yang dikeluarkan. Penerimaan dipengaruhi oleh jumlah produksi yang dihasilkan dan tingkat harga yang berlaku pada saat dijual. Pendapatan usahatani dihitung dengan rumus:

$\begin{aligned} \Pi & =\mathrm{TR}-\mathrm{TC} . . . \\ \mathrm{TR} & =\mathrm{Y} . \mathrm{Py} \ldots . . . \\ \mathrm{TC} & =\mathrm{FC}+\mathrm{VC}\end{aligned}$
Keterangan
$\Pi=$ Pendapatan
$\mathrm{TR}=$ Total Revenue (penerimaan total)
$\mathrm{TC}=$ Total Cost $($ Biaya Total)
$\mathrm{Y}=$ Produksi yang diperoleh
Py $=$ Harga $Y$
$\mathrm{FC}=$ Fixed Cost (Biaya Tetap)
$\mathrm{VC}=$ Variable cost (Biaya Tidak Tetap)

Analisis pendapatan digunakan mengetahui langkah yang tepat dalam melakukan usahatani cabai merah pada musim kemarau ataupun musim hujan agar tidak mengalami kerugian. Metode ini juga digunakan pada penelitian Kesuma, Zakaria, dan Situmorang (2015) serta Aini, Prasmatiwi, dan Sayekti (2015).
Faktor-faktor yang mempengaruhi keuntungan dianalisis menggunakan fungsi Cobb Douglas kemudian dianalisis menggunakan anlisis linear berganda yang ditransformasi. Uji regresi berganda adalah alat analisis peramalan nilai pengaruh dua variabel bebas atau lebih terhadap satu variabel terikat (untuk membuktikan ada atau tidaknya hubungan fungsional atau hubungan kausal antara dua variabel bebas atau lebih $\left(\mathrm{X}_{1}\right)$ $\left(\mathrm{X}_{2}\right)\left(\mathrm{X}_{3}\right) \ldots . .\left(\mathrm{X}_{\mathrm{n}}\right)$ dengan satu variabel terikat (Riduan 2009). Metode analisis yang kedua menggunakan fungsi keuntungan Cobb-Douglas UOP (Unit Output Price) yang diturunkan dari fungsi produksi CobbDouglas atau dari persamaan fungsi produksi yang telah dilogaritma normalkan yang dikalikan dengan harganya, sehingga diperoleh persamaan:

$$
\begin{aligned}
\operatorname{Ln} \pi^{*}= & \operatorname{Ln} A+\alpha_{1} \operatorname{Ln} \operatorname{Px}_{1}^{*}+\alpha_{2} \operatorname{Ln} \operatorname{Px}_{2} *+\alpha_{3} \operatorname{Ln} \\
& \operatorname{Px}_{3} *+\ldots \ldots .+\alpha_{8} \operatorname{Ln} \operatorname{Px}_{8} *+\beta_{1} \operatorname{Ln} \mathrm{Z}_{1}+\mathrm{e} . .(6)
\end{aligned}
$$

Keterangan:

$\pi^{*}=$ keuntungan usahatani telah dinormalkan dengan harga cabai merah besar

A = intersep usahatani cabai merah besar

$\mathrm{Px}_{1}{ }^{*}=$ harga benih yang telah dinormalkan dengan harga cabai

$\mathrm{Px}_{2}{ }^{*}=$ harga pupuk SP36 yang telah dinormalkan dengan harga cabai

$\mathrm{Px}_{3} *=$ harga pupuk kandang telah dinormalkan dengan harga cabai .

$\mathrm{Px}_{4} *=$ upah pupuk TSP yang telah dinormalkan dengan harga cabai

$\mathrm{Px}_{5}{ }^{*}=$ harga pupuk NPK telah dinormalkan dengan harga cabai

$\mathrm{Px}_{6}{ }^{*}=$ harga insektisida yang telah dinormalkan dengan harga cabai

$\mathrm{Px}_{7}{ }^{*}=$ harga fungisida telah dinormalkan dengan harga cabai .

$\mathrm{Px}_{8}{ }^{*}=$ upah tenaga kerja yang telah dinormalkan dengan harga cabai

$Z_{1} \quad=$ luas lahan usahatani cabai .

$\alpha_{1}=$ parameter input variabel usahatani cabai merah yang diduga $(1,2,3, . .6)$

$\beta_{1}=$ parameter input tetap usahatani cabai merah yang diduga

e $\quad$ faktor kesalahan usahatani cabai (standard eror).

Faktor-faktor yang mempengaruhi keuntungan usahatani cabai merah besar dianalisis dengan menggunakan persamaan fungsi keuntungan. Analisis data kuantitatif dilakukan dengan menggunakan data-data hasil dari identifikasi faktor-faktor yang mempengaruhi keuntungan yang dihasilkan pada kegiatan usahatani cabai 
merah. Pengolahan data untuk pendapatan dan faktor-faktor yang memengaruhi keuntungan menggunakan bantuan program Microsoft Excel, SPSS dan E-views. Pengujian ini dilakukan dengan 2 uji, yaitu:

a. Uji Asumsi Klasik

Uji asumsi klasik dibagi menjadi tiga yaitu multikolinearitas, heterokedastisitas dan normalitas. Uji normalitas dilakukan untuk mengetahui apakah nilai residual terdistribusi normal atau tidak. Jika nilai Asymp. Sig. kurang dari 0,05 maka distribusinya tidak normal, sedangkan jika nilai Asymp. Sig. lebih dari atau sama dengan 0,05 maka distribusinya normal. Uji multikolinearitas dilakukan untuk melihat ada tidaknya hubungan yang sangat kuat antar variabel bebas. Kriterianya adalah jika nilai VIF kurang dari 10 maka tidak terjadi multikolinearitas. Uji heterokedastisitas bertujuan untuk menguji apakah dalam sebuah model regresi terjadi ketidaksamaan varians residual dari suatu pengamatan ke pengamatan yang lain tetap (Santoso 2000). Pengambilan keputusan dalam uji ini dilakukan dengan cara uji white, apabila nilai prob. chi square lebih besa dari 0,05 maka tidak terjadi heterokedastisitas.

\section{b. Uji Statistilk}

Sugiyanto (2007) menyatakan bahwa pengujian parameter secara keseluruhan atau simultan menggunakan uji-F dimaksudkan untuk menguji apakah seluruh variabel bebas yang ada dalam model berpengaruh nyata terhadap hasil produksi apabila digunakan secara bersama-sama sedangkan keberartian koefisienkoefisien regresi dilakukan dengan menggunakan uji-t (Student test) dan pengukuran ketepatan model yang digunakan dapat diuji menggunakan uji determinasi (Winarno 2007).

\section{HASIL DAN PEMBAHASAN}

\section{Karakteristik Responden}

Berdasarkan hasil penelitian, rata-rata umur responden terbanyak antara 41-50 tahun (60\%). Responden yang melakukan usahatani cabai merah tergolong pada umur produktif. Tingkat pendidikan sebagian besar petani cabai merah adalah lulusan SD sebesar 42 persen. Pengalaman berusahatani cabai merah rata-rata selama 1-1 tahun (60\%). Jumlah tanggungan keluarga petani terbanyak adalah 3-4 orang (51\%).

\section{Budidaya Usahatani Cabai Merah}

Benih yang digunakan oleh petani cabai merah besar di Kecamatan Tulang Bawang Tengah adalah benih hibrida Lado F1. Petani cabai merah besar membeli benih di kios-kios pertanian yang ada di sekitar tempat tinggal mereka dengan harga Rp130.000,00 sampai dengan Rp170.000,00 per bungkus. Benih cabai merah besar varietas hibrida jenis Lado F1 memiliki keunggulan yaitu tanaman all season, yaitu dapat ditanam diberbagai musim. Berat satu bungkus benih Lado F1 adalah 10 gram yang berisi 1.750 butir benih cabai merah. Penggunaan benih cabai merah besar oleh petani di Kecamatan Tulang Bawang Tengah belum sesuai anjuran. Hal ini karena, rata-rata penggunaan benih cabai merah di Kecamatan Tulang Bawang Tengah sebesar 0,13 kilogram dengan biaya sebesar Rp1.858.123,68 per hektar, sedangkan menurut Syukur, Yunianti dan Dermawan (2018), kebutuhan benih cabai setiap hektar pertanaman adalah 0,04 kilogram .

Petani di Kecamatan Tulang Bawang Tengah melakukan pemupukan sebanyak empat kali. Pemupukan dasar dilakukan petani pasca pengolahan tanah, biasanya 5-7 hari sebelum tanam. Rata-rata harga pupuk NPK di Kecamatan Tulang Bawang Tengah sekitar Rp8.810,18/kilogram, pupuk kandang Rp353,86/kilogram, pupuk SP36 Rp2.735,09/kilogram, dan pupuk TSP Rp6.541,23/kilogram. Pemupukan dilakukan empat kali dalam sekali musim tanam. Pemupukan pertama dilakukan pada saat sebelum tumbuhan cabai merah dipindahkan ke lahan, sedangkan pemupukan susulan dilakukan setelah tanaman dipindahkan ke lahan. Biaya pupuk yang digunakan petani cabai yaitu Rp11.885.968 per hektar.

Pestisida yang digunakan dalam usahatani cabai merah di Kecamatan Tulang Bawang Tengah adalah Albenz, Virtako, Regent, Endure, Sapporo, Furadan, Curacon, Cigal, Zampro dan Amistar Top. Pestisida digunakan untuk membasmi hama dan penyakit secara alami maupun kimia. Total biaya yang dikeluarkan untuk seluruh pembelian dalam satu kali musim tanam yaitu sebesar Rp5.662.044,54. per hektar. Pestisida yang dominan digunakan oleh petani adalah jenis fungisida dengan merk dagang Cigal. Hal ini karena organisme yang paling banyak menyerang adalah bakteri atau jamur. Jenis hama yang paling banyak menyerang adalah ulat grayak, kutu kebul, 
kutu daun dan lalat buah, sehingga petani juga menggunakan insektisida.

Rata-rata penggunaan mulsa per hektar adalah sebesar 102 kilogram. Harga mulsa yang dibeli oleh masing-masing petani berada pada kisaran Rp30.000,00 - Rp40.000,00 per kilogram. Perbedaan harga disebabkan perbedaan merk mulsa yang dibeli oleh petani. Mulsa yang digunakan petani cabai merah adalah mulsa plas hitam perak. Manfaat mulsa hitam ada menekan pertumbuhan gulma, menjaga tanah telap subur, menjaga kestabilan suhu dan kelembaban tanah. Biaya pemasangan mulsa per hektar yaitu sebesar Rp3.690.924,32.

Penggunaan selang drip per hektar adalah sebesar 13 roll dengan biaya Rp1.146.517,15 per hektar. Harga selang drip yang dibeli oleh masing-masing petani berada pada kisaran Rp90.000,00Rp100.000,00 per roll. Perbedaan harga disebabkan perbedaan merek selang drip yang dibeli oleh petani. Selang drip digunakan untuk mengalirkan air agar memudahkan petani dalam melakukan penyiraman. Penggunaan selang drip dilakukan dengan bantuan pompa air atau alkon.

Menurut Astusi, Ismono dan Situmorang (2013), faktor aplikasi budidaya cabai merah meliputi jumlah tenaga kerja. Penggunaan tenaga kerja dalam keluarga (TKDK) dan tenaga kerja luar keluarga (TKLK) tertinggi yaitu pada kegiatan panen dengan HOK yaitu sebesar 105 yang terdiri dari tenaga kerja dalam keluarga sebesar $32 \mathrm{HOK}$ dan tenaga kerja luar keluarga sebesar 73 HOK. Upah pria dan upah wanita yang dibayar petani sebesar Rp35.000,00. Biaya tenaga kerja keseluruhan usahatani cabai merah yaitu sebesar Rp40.377.192,90 per hektar.

Peralatan yang digunakan petani adalah cangkul, sprayer, ember, golok, arit, pompa air, drum air, dan ajir. Biaya penyusutan tertinggi adalah ajir. Hal ini karena penggunaan ajir mencapai Rp1.350.642,21 per hektar. Ajir yang digunakan pada usahatani cabai merah di Kecamatan Tulang Bawang Tengah terbuat dari bambu dan juga ranting pohon karet yang banyak terdapat di Kecamatan ini.

Petani melakukan kegiatan panen setiap 2-5 hari sekali dengan menyesuaikan tingkat kematangan buah. Rata-rata produksi cabai merah di Kecamatan Tulang Bawang Tengah per hektar adalah sebesar 4.964,39 kilogram. Harga jual pada MT 1 cenderung menurun dibandingkan musim
Tabel 1. Rata-rata produksi, harga dan penerimaan usahatani cabai merah per hektar MT 2018 di Kecamatan Tulang Bawang Tengah

\begin{tabular}{lrcc}
\hline Waktu Petik & $\begin{array}{c}\text { Produksi } \\
\text { (Kg) }\end{array}$ & $\begin{array}{c}\text { Harga } \\
(\mathbf{R p})\end{array}$ & $\begin{array}{c}\text { Penerimaan } \\
\text { ha }(\mathbf{R p})\end{array}$ \\
\hline Petik ke-1 & 16,56 & $19.421,05$ & $1.148 .713,89$ \\
Petik ke-2 & 37,25 & $19.219,30$ & $2.556 .552,00$ \\
Petik ke-3 & 89,90 & $20.245,61$ & $6.500 .541,93$ \\
Petik ke-4 & 83,32 & $21.356,14$ & $6.355 .325,11$ \\
Petik ke-5 & 104,1 & $21.736,84$ & $8.081 .447,36$ \\
Petik ke-6 & 220,83 & $20.122,81$ & $15.870 .666,25$ \\
Petik ke-7 & 103,11 & $19.508,77$ & $7.184 .386,39$ \\
Petik ke-8 & 114,83 & $17.229,82$ & $7.066 .279,25$ \\
Petik ke-9 & 144,43 & $15.947,37$ & $8.225 .984,36$ \\
Petik ke-10 & 160,02 & $15.790,35$ & $9.024 .047,00$ \\
Petik ke-11 & 100,64 & $19.912,28$ & $7.157 .067,57$ \\
Petik ke-12 & 69,50 & $24.175,44$ & $6.000 .689,21$ \\
Petik ke-13 & 48,18 & $23.868,42$ & $4.106 .684,46$ \\
Petik ke-14 & 47,98 & $24.070,18$ & $4.124 .807,64$ \\
Petik ke-15 & 34,68 & $19.359,65$ & $2.398 .121,96$ \\
Petik ke-16 & 14,68 & $20.245,61$ & $1.106 .753,07$ \\
\hline Total produksi rata-rata per 1 ha (Kg) & $4.964,39$ \\
Harga rata-rata (Rp) & & $20.138,10$ \\
\hline
\end{tabular}

tanam sebelumnya. Hal ini karena, panen yang dilakukan serentak, karena pasokan yang tersedia banyak. Puncak produksi tertinggi berada pada panen ke-6 dengan rata-rata sebesar 220,30. Ratarata produksi, harga dan penerimaan usahatani cabai merah per hektar MT 2018 di Kecamatan Tulang Bawang Tengah dapat dilihat pada Tabel 1.

Berdasarkan Tabel 1, harga cabai merah termasuk rendah hingga menyentuh angka Rp15.79,35 per kilogram dari harga tertinggi Rp24.175,44 per kilogram. Kegiatan panen ke-6 dan 10 merupakan puncak hasil produksi yang biasa disebut petani panen agung. Panen cabai merah dilakukan sebanyak enam belas kali panen, dengan produksi dan harga jual yang berbeda-beda. Kegiatan usahatani cabai merah memerlukan waktu selama $100-120$ hari hingga panen.

\section{Pendapatan Usahatani Cabai Merah di Kecamatan Tulang Bawang Tengah}

Biaya produksi dalam usahatani cabai merah dalam penelitian ini dibagi menjadi dua macam, yaitu biaya tunai dan biaya diperhitungkan yang dihitung selama satu musim tanam. Biaya tunai pada usahatani cabai merah di Kecamatan Tulang Bawang Tengah, Kabupaten Tulang Bawang Barat adalah biaya benih, pupuk, pestisida, mulsa, selang drip, dan tenaga kerja di luar keluarga (TKLK). Total biaya tunai yang diperoleh sebesar Rp50.141.285,30 per hektar sedangkan total biaya diperhitungkan sebesar Rp25.003.548,14 per 
hektar. Biaya tertinggi dari biaya tunai yang dikeluarkan oleh petani cabai merah di Kecamatan adalah biaya tenaga kerja luar keluarga sebesar Rp25.993.421,05 per hektar.

Berdasarkan Tabel 2, biaya TKLK tunai sebagai biaya tertinggi yang dikeluarkan petani, hal ini karena panen cabai merah di Kecamatan Tulang Bawang Tengah dilakukan sebanyak enam belas kali. Biaya dari total biaya terbesar adalah biaya tenaga kerja luar keluarga yaitu sebesar Rp18.143.258,98 per hektar. Nilai R/C atas biaya tunai yang diperoleh pada usahatani cabai merah adalah 1,99 artinya dari setiap satu rupiah yang dikeluarkan petani sebagai biaya tunai untuk usahataninya dapat menghasilkan tambahan penerimaan sebesar $\mathrm{Rp} 1,99$. Nilai $\mathrm{R} / \mathrm{C}$ atas total biaya yang diperoleh pada usahatani cabai merah sebesar 1,33 artinya dari setiap satu rupiah yang dikeluarkan petani sebagai total biaya untuk usahataninya dapat menghasilkan penambahan penerimaan sebesar $\mathrm{Rp}$ 1,33. Hal ini selaras dengan pernyataan Nisa, Haryono, dan Muniarti (2018) dan Chonani, Prasmatiwi, dan Santoso (2014) penelitian yang menyatakan bahwa nilai $\mathrm{R} / \mathrm{C}>1$ menunjukkan bahwa usahatani yang dilakukan menguntungkan. Komponen biaya usahatani dan pendapatan cabai merah per hektar MT 2018 di Kecamatan Tulang Bawang Tengah dapat dilihat pada Tabel 2.

\section{Faktor-faktor yang Mempengaruhi Keuntungan Usahatani Cabai Merah}

Berdasarkan hasil analisis diperoleh nilai sig Fhitung fungsi keuntungan sebesar 0,000 artinya variabel luas lahan, harga benih, harga pupuk SP36, harga pupuk kandang, harga pupuk TSP, harga pupuk NPK, harga insektisida, harga fungisida dan upah tenaga kerja secara bersamasama berpengaruh nyata terhadap keuntungan usahatani cabai merah.

Tabel 2. Komponen biaya usahatani dan pendapatan cabai merah per hektar MT 2018 di Kecamatan Tulang Bawang Tengah

\begin{tabular}{|c|c|c|c|c|}
\hline \multirow{2}{*}{ Uraian } & \multicolumn{4}{|c|}{ per hektar } \\
\hline & Jumlah & Satuan & Jumlah & Total Nilai (Rp) \\
\hline Penerimaan & 1390 & $\mathrm{Kg}$ & 4.964 & $99.973 .442,42$ \\
\hline \multicolumn{5}{|l|}{ Biaya Produksi } \\
\hline \multicolumn{5}{|l|}{ 1. Biaya Tunai } \\
\hline Bibit Lado & 0,04 & $\mathrm{Kg}$ & 0,13 & $1.867 .701,75$ \\
\hline Pupuk Kandang & 5870 & $\mathrm{Kg}$ & 20.965 & 7.418.658,68 \\
\hline Pupuk TSP & 66 & $\mathrm{Kg}$ & 235 & $1.536 .532,83$ \\
\hline Pupuk NPK Mutiara & 76 & $\mathrm{Kg}$ & 272 & 2.394.093,41 \\
\hline Pupuk SP36 & 64 & $\mathrm{Kg}$ & 230 & $628.247,59$ \\
\hline Insektisida Abenz & 7 & $\mathrm{~L}$ & 26 & $953.383,46$ \\
\hline Insektisida Virtako & 41 & $\mathrm{~L}$ & 145 & $1.485 .964,91$ \\
\hline Insektisida Regent & 20 & $\mathrm{~L}$ & 72 & $469.194,37$ \\
\hline Insektisida Endure & 10 & $\mathrm{~L}$ & 36 & $565.476,19$ \\
\hline Insektisida Furadan & 40 & $\mathrm{Gr}$ & 143 & $71.428,57$ \\
\hline Insektisida Sapporo & 5 & $\mathrm{~L}$ & 16 & $569.548,87$ \\
\hline Insektisida Curacon & 48 & $\mathrm{~L}$ & 171 & $276.597,74$ \\
\hline Fungisida Cigal & 107 & $\mathrm{~L}$ & 381 & $476.190,48$ \\
\hline Fungisida Zampro & 56 & $\mathrm{~L}$ & 201 & $343.984,96$ \\
\hline Fungisida Amistar Top & 31 & $\mathrm{~L}$ & 112 & $192.615,47$ \\
\hline Mulsa & 29 & $\mathrm{Kg}$ & 102 & $3.690 .924,32$ \\
\hline Pajak & 0,28 & $\mathrm{Ha} / \mathrm{MT}$ & 1 & $60.803,47$ \\
\hline Selang drip & 4 & Roll & 13 & $1.146 .517,15$ \\
\hline TK Luar Keluarga & 208 & HOK & 743 & $25.993 .421,05$ \\
\hline Total Biaya Tunai & & & & $50.141 .285,30$ \\
\hline \multicolumn{5}{|l|}{ 2. Biaya diperhitungkan } \\
\hline Sewa Lahan & 0,28 & $\mathrm{Ha}$ & 1 & $6.000 .000,00$ \\
\hline TK dalam Keluarga & 115 & HOK & 411 & $14.383 .771,93$ \\
\hline Biaya lain-lain & & & & $3.440 .958,53$ \\
\hline Penyusutan Alat & & & & $1.178 .817,68$ \\
\hline Total Biaya diperhitungkan & & & & $25.003 .548,14$ \\
\hline 3. Total Biaya & & & & $75.144 .833,44$ \\
\hline \multicolumn{5}{|l|}{ Pendapatan } \\
\hline 1. Pendapatan Atas Biaya Tunai & & & & $47.486 .701,79$ \\
\hline 2. Pendapatan Atas Biaya Total & & & & $22.229 .238,35$ \\
\hline R/C Biaya Tunai & & & & 1,99 \\
\hline $\mathrm{R} / \mathrm{C}$ Biaya Total & & & & 1,33 \\
\hline
\end{tabular}


Nilai R-squared pada adalah sebesar 0.919 atau 91,9 persen, artinya sebesar 91,9 persen variasi keuntungan usahatani cabai merah besar dapat diterangkan oleh variabel independen.sedangkan sisanya 8,1 persendijelaskan oleh variabel lain yang tidak dimasukan dalam model.

Variabel luas lahan berpengaruh nyata terhadap keuntungan yaitu dengan tingkat kepercayaan sebesar 99 persen. Variabel luas lahan mempunyai koefisien sebesar 0,827 yang mempunyai pengaruh positif, artinya apabila terjadi kenaikan luas lahan sebesar 1 persen, maka terjadi kenaikan keuntungan sebesar 0,827 persen. Hal ini sejalan dengan penelitian Hernanto (2009) besar kecilnya produksi usahatani lain dipengaruhi oleh luas sempitnya lahan yang digunakan, sekalipun luas lahan berpengaruh positif terhadap penigkatan produksi cabai merah besar.

Variabel harga pupuk kandang berpengaruh nyata terhadap keuntungan dengan tingkat kepercayaan sebesar 99 persen. Variabel harga pupuk kandang mempunyai koefisien sebesar -0,332 yang mempunyai pengaruh negatif, artinya apabila terjadi kenaikan harga pupuk kandang sebesar 1 persen, maka terjadi penurunan keuntungan sebesar 0,332 persen

Variabel harga pupuk NPK berpengaruh nyata terhadap keuntungan dengan tingkat kepercayaan sebesar 90 persen. Variabel harga pupuk NPK mempunyai koefisien sebesar $-0,280$ yang mempunyai pengaruh negatif, artinya apabila terjadi kenaikan harga pupuk NPK sebesar 1 persen, maka terjadi penurunan keuntungan sebesar 0,280 persen.

Variabel harga insektisida berpengaruh nyata terhadap keuntungan dengan tingkat keperayaan sebesar 95 persen. Variabel harga insektisida mempunyai koefisien sebesar $-0,198$ yang mempunyai pengaruh negatif, artinya apabila terjadi kenaikan harga insektisida sebesar 1 persen, maka terjadi penurunan keuntungan sebesar 0,198 persen.

Variabel upah tenaga kerja berpengaruh nyata terhadap keuntungan dengan tingkat kepercayaan sebesar 99 persen. Variabel upah tenaga kerja mempunyai koefisien sebesar -1,461 yang mempunyai pengaruh negatif, artinya apabila terjadi kenaikan upah tenaga kerja sebesar 1 persen, maka terjadi penurunan keuntungan sebesar 1,461 persen.
Tabel 3. Analisis fungsi keuntungan usahatani cabai merah per hektar MT $2018 \mathrm{di}$ Kecamatan Tulang Bawang Tengah

\begin{tabular}{lcrrr}
\hline \multicolumn{1}{c}{ Variabel } & $\begin{array}{c}\text { Koef. } \\
\text { Regresi }\end{array}$ & t-hitung & Sig & VIF \\
\hline (Constant) & $-0,415$ & $-0,367$ & 0,716 & \\
Luas Lahan & $0,827 * * *$ & 8,506 & 0,000 & 2,122 \\
Harga benih & $-0,322^{* *}$ & $-2,593$ & 0,013 & 1,313 \\
Harga pupuk SP36 & $-0,140$ & $-1,392$ & 0,170 & 1,208 \\
Harga pupuk & & & & \\
kandang & $-0,322^{* * *}$ & $-5,631$ & 0,000 & 1,159 \\
harga pupuk TSP & $-0,161$ & $-1,298$ & 0,201 & 1,195 \\
Harga pupuk NPK & $-0,280^{*}$ & $-1,725$ & 0,091 & 1,282 \\
Harga Insektisida & $-0,198^{* *}$ & $-2,146$ & 0,037 & 1,692 \\
Harga fungisida & $-0,222^{* * *}$ & $-3,528$ & 0,001 & 1,476 \\
upah tenaga kerja & $-1,461 * * *$ & $-12,166$ & 0,000 & 1,671 \\
$\mathrm{R}$ & 0,959 & & & \\
$\mathrm{R}^{2}$ & 0,919 & & & \\
$\mathrm{R}^{2}$ adjusted & 0,903 & & & \\
F-hitung & 59.093 & & 0,000 & \\
\hline Keterangan : & & & &
\end{tabular}

Keterangan :

*) Tingkat kepercayaan $90 \%$

**) Tingkat kepercayaan $95 \%$

***) Tingkat kepercayaan $99 \%$

Variabel harga benih berpengaruh nyata terhadap keuntungan yaitu dengan tingkat kepercayaan sebesar 95 persen. Variabel harga benih mempunyai koefisien sebesar $-0,322$ yang mempunyai pengaruh negatif, artinya apabila terjadi kenaikan harga benih sebesar 1 persen, maka terjadi penurunan keuntungan sebesar 0,322 persen.

Variabel harga fungisida berpengaruh nyata terhadap keuntungan dengan tingkat kepercayaan sebesar 99 persen. Variabel harga fungisida mempunyai koefisien sebesar -0,222 yang mempunyai pengaruh negatif, artinya apabila terjadi kenaikan harga fungisida sebesar 1 persen, maka terjadi penurunan keuntungan sebesar 0,222 persen. Hal ini sejalan dengan penelitian terdahulu oleh Sofa, Saparto, dan Wiharso (2019) bahwa harga pestisida berpengaruh nyata terhadap peningkatan hasil produksi, dosis yang digunakan dapat ditingkatkan sesuai dengan kondisi lapangan sesuai dengan intensitas hama/penyakit yang menyerang. Analisis fungsi keuntungan usahatani cabai merah per hektar MT 2018 di Kecamatan Tulang Bawang Tengah dapat dilihat pada Tabel 3.

\section{KESIMPULAN}

Pendapatan atas biaya tunai yang diperoleh sebesar Rp47.486.701,79 sedangkan pendapatan atas biaya total sebesar Rp22.219.238,35. Nilai R/C atas biaya tunai dari penelitian ini dapat dikatakan layak karena lebih besar dari 1. Faktor-faktor 
yang mempengaruhi keuntungan usahatani cabai merah di Kecamatan Tulang Bawang Tengah adalah harga benih, harga pupuk kandang, harga pupuk NPK, harga insektisida, harga fungisi harga pupuk SP36 dan upah tenaga kerja.

\section{DAFTAR PUSTAKA}

Aini HN, Prasmatiwi FE, dan Sayekti WD. 2015. Analisis pendapatan dan risiko usahatani kubis pada lahan kering dan lahan sawah tadah hujan di Kecamatan Gisting Kabupaten Tanggamus. Jurnal Ilmu Ilmu Agribisnis, 3 (1) $1-9$. http://jurnal.fp.unila.ac.id/index.php/JIA/articl e/view/1011 /916. [15 April 2020]

Astuti P, Ismono RH, dan Situmorang S. 2013. Faktor-faktor penyebab rendahnya minat petani untuk menerapkan budidaya cabai merah ramah lingkungan di Kabupaten Lampung Selatan. Jurnal Ilmu Ilmu $\begin{array}{llr}\text { Agribisnis, } & 1(1) \quad \text { : }\end{array}$ http://jurnal.fp.unila.ac.id/index.php/JIA/articl e/view/136/140. [ 13 Desember 2019]

BPS [Badan Pusat Statistik]. 2017. Tulang Bawang Barat dalam Angka. BPS Kabupaten Tulang Bawang Barat. Panaragan Jaya. https://tulangbawangbaratkab.bps.go.id/public ation/2017/08/11/b9661081a76d692f5b56e83 1/kabupaten-tulang-bawang-barat-dalamangka-2017.html. [08 Januari 2019]

BPS [Badan Pusat Statistik]. 2017. Permintaan Nasional Cabai Merah. BPS. Indonesia. https://www.bps.go.id/publication/2018/10/05 /bbd90b867a6ee372e7f51c43/statistiktanaman-sayuran-dan-buah---buahansemusim-indonesia-2017.html. [08 Januari 2019].

BPS [Badan Pusat Statistik]. 2018. Tingkat Konsumsi Cabai Merah Nasional. BPS. Indonesia.

https://www.bps.go.id/publication/2019/02/27 /7f31ac3ebaff80622d8a4c18/distribusiperdagangan-komoditas-cabai-merah-diindonesia-2018.html. [08 Januari 2019]

Chonani SH, Prasmatiwi FE, dan Santoso H. 2014. Efisiensi produksi dan pendapatan usahatani cabai merah di Kecamatan Metro Kibang Kabupaten Lampung Timur:pendekatan fungsi produksi frontier. Jurnal Ilmu Ilmu Agribisnis, 2(2) : 95-102. http://jurnal.fp.unila.ac.id/index.php/JIA/articl e/view/730/672. [ 13 Desember 2018]

Direktorat Jenderal Hortikultura Provinsi Lampung. 2017. Provinsi Lampung dan
Direktorat Jendral Hortikultura dalam Angka. Direktorat Jendral Hortikultura Provinsi Lampung. Bandar Lampung. http://hortikultura2.pertanian.go.id/produksi/s ayuran.php?page $=2$. [08 Januari 2019]

Kecamatan Tulang Bawang Tengah. 2018. Data Kecamatan Tulang Bawang Tengah. Tulang Bawang Tengah.

Kesuma R, Zakaria WA, dan Situmorang S. 2015. Analisis usahatani dan pemasaran bawang merah di Kabupaten Tanggamus. Jurnal Ilmu Ilmu Agribisnis, 4(1) : 1-7. www.jurnal.fp.unila.ac.id/ index.php/JIA/article/view/1208/1105. April 2020].

Nazir M. 2005. Metode Penelitian. Ghalia Indonesia. Bogor.

Nisa UC, Haryono D, dan Muniarti K. 2018. Pendapatan usahatani cabai merah di Kecamatan Kalianda Kabupaten Lampung Selatan. Jurnal Ilmu Ilmu Agribisnis, 6(2): 149-156.

http://jurnal.fp.unila.ac.id/index.php/JIA/articl e/view/2780/2326. [5 Januari 2019]

Nofita IA, Sutiarso dan Hadi S. 2016. Analisis keuntungan usahatani cabai merah besar di Desa Andongsari Kecamatan Ambulu Kabupaten Jember. Agritrop Jurnal IlmuIlmu Pertanian, 2(6) : 166-170. https://media.neliti.com/media/publications/27 3709-analisis-keuntungan-usahatani-cabaimera-b9aa493d.pdf. [5 November 2019]

Santoso S. 2000. Latihan SPSS Statistik Parmetik. Gramedia. Jakarta.

Sofa MF, Saparto dan Wiharso. 2019. Pengaruh biaya sarana produksi dan tenaga kerja terhadap pendapatan usahatani cabai rawit merah di Desa Kesambi Kecamatan Mejobo Kabupaten Kudus. Sekolah Tinggi Ilmu Pertanian Farming Semarang, 37(1) : 92-101. http://www.jurnalkampus.stipfarming.ac.id/in dex.php/am/aricle/view/file/249/217. November 2018]

Sugiyanto C. 2007. Materi Pokok Ekonometrika. Universitas Terbuka. Jakarta.

Sugiyono. 2010. Metode Penelitian Pendidikan Pendekatan Kuantitatif, Kualitatif dan $R \& D$. Alfabeta. Bandung.

Syukur M, Yunianti R, dan Dermawan R. 2018. Budidaya Cabai Panen Setiap Hari. Penebar Swadaya. Jakarta.

Winarno WW. 2007. Analisis Ekonometrika dan Statistika dengan Eviews. UPP STIM YKPN. Yogyakarta. 